\title{
EHMTI-0207. Abnormal brain excitability and cognitive dysfunction in adolescents with chronic daily headache
}

\author{
A Sergeev $^{1 *}$, A Ratchin $^{2}$, T Avdeeva $^{2}$, G Tabeeva $^{1}$ \\ From 4th European Headache and Migraine Trust International Congress: EHMTIC 2014 \\ Copenhagen, Denmark. 18-21 September 2014
}

\section{Introduction}

People with daily chronic headache $(\mathrm{CDH})$ commonly report impaired cognitive function. However, cognitive dysfunction in patients with $\mathrm{CDH}$ is poorly studied.

\section{Aims}

We studied cognitive event related potential P300 elected by specific visual verbal and non-verbal stimuli "Headache" at adolescents with daily chronic headache (CDH).

\section{Methods}

We recorded cognitive event related potential (ERP) P300 (significant stimuli - verbal (the word - «headache») and non-verbal (the image «headache»)) in 14 healthy adolescents and in 14 age, gender and socio-economic matched $\mathrm{CDH}$ patients. To test the ERP habituation, three consecutive blocks were recorded for P300 potential. Habituation of the ERPs P300 was defined as the \% change of the N2/P3 amplitude between the 1st and 3rd block.

\section{Results}

There was no difference in either the grant average N2/P3 latency or the grant average N2/P3 amplitudes as for verbal $(323,8 \pm 70,8 \mathrm{~ms} ; 19,6 \pm 5,5 \mathrm{mV}$ and for the grant average latency and the amplitudes $\mathrm{P} 300$, respectively) as for non-verbal $(342,4 \pm 64,2 \mathrm{~ms} ; 21,2 \pm 6,1 \mathrm{mV}$ for the grant average latency and the amplitudes P300 potential, respectively) stimuli at $\mathrm{CDH}$ group compared with controls.

During repeating stimulation (three blocks of stimuli) there was significant lack of habituation in $\mathrm{CDH}$ patients at specific verbal $(+3,5 \%)$ and non-verbal stimuli $(+0,8 \%)$ compared with controls $(-15,6 \%$ and $-13,4 \%$, respectively).

'Department of Neurology, I.M. Sechenov First Moscow State Medical University, Moscow, Russia

Full list of author information is available at the end of the article

\section{Conclusions}

The lack of habituation in response to significant verbal and non-verbal stimuli points to the increase of relevance to cognitive function at $\mathrm{CDH}$ group. The results point at the development of memory and cognitive dysfunction in adolescents with $\mathrm{CDH}$

No conflict of interest.

\section{Authors' details}

'Department of Neurology, I.M. Sechenov First Moscow State Medical University, Moscow, Russia. ${ }^{2}$ Department of Neurology, Smolensk State Medical Academy, Smolensk, Russia.

Published: 18 September 2014

doi:10.1186/1129-2377-15-S1-E35

Cite this article as: Sergeev et al:: EHMTI-0207. Abnormal brain excitability and cognitive dysfunction in adolescents with chronic daily headache. The Journal of Headache and Pain 2014 15(Suppl 1):E35.

\section{SpringerOpen ${ }^{\odot}$}

(C) 2014 Sergeev et al; licensee Springer. This is an Open Access article distributed under the terms of the Creative Commons Attribution License (http://creativecommons.org/licenses/by/2.0), which permits unrestricted use, distribution, and reproduction in any medium, provided the original work is properly cited.
Submit your manuscript to a SpringerOpen ${ }^{\circ}$ journal and benefit from:

- Convenient online submission

- Rigorous peer review

- Immediate publication on acceptance

- Open access: articles freely available online

- High visibility within the field

- Retaining the copyright to your article

Submit your next manuscript at $>$ springeropen.com 